\title{
生殖年齢にある女性透析患者の 月経周期に関する基礎的研究
}

\author{
岩崎 和 代 \\ 国際医療福祉大学保健医療学部看護学科
}

\section{はじめに}

近年，腎性貧血改善剂の使用等により身体的 $\mathrm{QOL}$ 向上に関する報告がある。これに伴い生殖年齢にある 女性透析患者の性周期の改善が指摘されている。本研 究は, 生殖年齢にある女性透析患者の身体的 QOL 改 善指標の 1 つと考える性周期の実態を明らかにし, 生 殖年齢にある女性透析患者の支援に関する示唆を得る ことを目的とした。

\section{I. 方 法}

\section{1. 調查対象・期間}

甲信越圈にある透析ベッド数約 130 床を抱える透析 専門病院に調査を依頼, 生殖年齢にある 8 名の調査協 力者を得た. 調查は平成 19 年 11 月から平成 20 年 3 月 (デー夕収集続行中).

\section{2. 調査方法}

調查協力者 8 名に対して性周期に関わる項目（初経 年齢， MBI，月経周期，月経前症候群などに関する自 覚症状の有無等）の聞き取り調査および継続的（最低 6 か月間）な基礎体温測定を依頼した。基礎体温計は 自動記憶機能をもつニシモト社製電子体温計プチソ フィアを用いた。

倫理的配慮として, 研究計画書拉よび調査内容の作 成後, 依頼病院の倫理審査委員会の承認を受けた。調 查協力者には, 調查主旨と個人情報保護等に関して口 頭と文書で説明し書面で承諾を得た。

\section{II. 結果}

対象者の平均年齢は $38.1 \pm$ 標準偏差 5.6 歳（範囲 26 42 歳), 原疾患の発病年齢 $17.1 \pm 8.6$ 歳, CGN
$50.0 \%$ ，ネフローゼ症候群・囊胞腎・家族性若年性ネ フロン・不明が各 $12.5 \%$, 全員が血液透析療法であり, 導入年齢は $26.4 \pm 9.2$ 歳だった。透析前 $\mathrm{Hb}$ は平均 $10.5 \pm 1.0 \mathrm{~g} / \mathrm{dL}$ で, 全員が週平均 $3,281.3 \pm 1,496.6$ 単位の腎性貧血改善剂を使用, 平均 dry weight は $49.8 \pm 7.0 \mathrm{~kg}$, BMI（に対する）は 20.4 (18.3〜24.2), 中 1 日体重増加率は平均 $4.8 \%$, 中 2 日で $7.0 \%$ であっ た.

初経年齢は $12.3 \pm 1.7$ 歳, 月経周期は $62.5 \%$ が不規 則であり, 透析導入前は月経が停止し, 導入後に再来 していた，既婚者の割合は $50.0 \%$ ，透析導入後の出産 経験者は 2 名でうち 1 名は 2 度の出産を経験，また不 妊治療経験者は 3 名,このうち 2 名は出産まで至った。 月経中のダイアライザーやヘパリン変更は $38.0 \%$ が 受け，半数以上が月経中もスタッフには報告していな かった。一方，透析中の月経は 87.5\%が煩わしく感 じ，半数が透析中の出血を危惧し， $37.5 \%$ は透析中の パッド漏れを経験した。 月経前症候群 20 項目のうち 頭痛・乳房の痛み・乳房の張り・帯下などの 11 項目で 自覚症状を経験し，月経中は腰痛などの 6 項目で症状 を自覚, 腰痛は強い・やや強いなど症状を自覚する割 合が半数を占めた，月経に関わりなく自覚する症状は 8 項目であったが，症状を有する割合は低かった，卵 巣囊腫や子宮筋腫を指摘されている割合は $25 \%$ で あった。

基礎体温記録 60 日間の内容をみると，1名を除き 24〜33 日周期で月経が確認されたが，基礎体温で排卵 性月経の可能性を示す $03{ }^{\circ} \mathrm{C}$ 以上の高温相と低温相の 差 2 相性を確認できたのは 2 名に留まった． 2 名のう ちすでに不妊治療中であった 1 名が，本調查中に体外 受精（卵子移植）を実施, 着床と妊娠継続が確認され た。

岩崎 和代 国際医療福祉大学保健医療学部看護学科％ $324-8501$ 栃木県大田原市北金丸 2600-1

Kazuyo Iwasaki Tel : 0287-24-3030 Fax : 0287-24-3192 E-mail : kiwasaki@iuhw.ac.jp 


\section{III. 考 察}

調查協力者は女性ホルモンの成熟を迎える思春期で 腎疾患を発病し, 多くが結婚・出産適齢期で透析に導 入となっていた，腎性貧血の改善により身体の不快症 状などの自覚症状の割合は低く, 透析間の体重増加率 をみても身体的 QOL の自覚は高いと考えられた。一 方，月経はあっても基礎体温から高温相を確認できな かった割合が多く，排卵性月経の不確かな実態がうか
がわれた，半数は既婚者であり，性的パートナーを有 する場合に思いがけない娃娠を経験する背景の一端が うかがわれた，月経中の透析は，出血量や腰痛・月経 漏れなどが気になっていたことも明らかになった。こ れら対象に対しては, 性周期に変動する女性ホルモン 值や今後の継続的な基礎体温結果を継続的に評価する とともに，支援のあり方を検討する必要があろう．1 名が本調查期間中に着床・妊娠継続が診断され, 八イ リスク妊娠ながら順調に経過していることは幸いであ る. 